\title{
Penghitungan Kebutuhan Tenaga Keperawatan Berdasarkan WISN di RS. Gotong Royong
}

\author{
Danoe Soesanto \\ Fakultas Kedokteran Universitas Ciputra, danususanto.ds@gmail.com \\ Triesnawati Ersyad \\ Fakultas Kedokteran Universitas Ciputra
}

\begin{abstract}
Abstrak
Kebutuhan tenaga perawat dihitung berdasarkan beban kerja nyata ditiap unit kerja Rumah Sakit disebut Workload Indicator Staffing Need (WISN) merupakan metode. Kebutuhan sumber daya manusia diunit kerja dan kategori dapat dihitung menggunakan metode WISN, waktu kerja tersedia tiap kategori sumber daya manusia, standar beban kerja, standar kelonggaran, banyaknya pekerjaan diunit kerja sehingga kebutuhan sumber daya manusia pada unit kerja dapat diketahui. Ketepatan, keakuratan dan kelengkapan data beban kerja sangat mempengaruhi metode WISN. Tujuan penelitian untuk mengetahui jumlah kebutuhan tenaga perawat di ruang rawat inap dewasa dan ruang rawat inap anak RS Gotong Royong. Metode penelitian menggunakan metode WISN, selanjutnya dilakukan perbandingan jumlah perawat yang ada di unit rawat inap. Hasil penelitian menyatakan kebutuhan tenaga perawat di ruang rawat inap dewasa (10 perawat) lebih banyak dibanding tenaga perawat di ruang rawat inap anak (8 perawat). Hal ini terjadi karena terdapat ketepatan dan kelengkapan data terkait dengan beban kerja yang teridentifikasi oleh metode Work Load Indicator Staff Needs. Kesimpulan dalam penelitian menyatakan metode WISN dapat digunakan dalam menghitung kebutuhan jumlah tenaga perawat sehingga kualitas pelayanan, kepuasan pasien dan tenaga kesehatan dapat ditingkatkan, tetapi terdapat hal-hal yang harus diperhatikan yaitu ketepatan mengidentifikasi kelengkapan data beban kerja. Peneliti menyarankan situasi, kondisi dan karakteristik rumah sakit menyesuaikan metode penghitungan kebutuhan tenaga yang lebih sesuai.
\end{abstract}

\section{Kata kunci: WISN, Perawat, Rawat Inap, Rumah Sakit}

\begin{abstract}
Workload Indicator Staffing Need (WISN) is a method of calculating the need for nurses based on real work load in each work unit of health facility. WISN method can know the work unit and its human resources category, working time available each category of human resources, workload standard, concession standard, quantity of main activity and finally can know the requirement of human resource at work unit. WISN method is highly dependent on the accuracy and completeness of workload data. The purpose of this study is to determine the number of nurse personnel needs in the inpatient wards and in-patient wards of the Gotong Royong Hospital. Mutual cooperation. The research method used is to calculate the number of nurses in hospital wards. Gotong Royong using WISN method, then make a comparison with the number of existing nurses. The study shows the number of nurses with WISN method more than in the adult admissions room (10 nurses) and 8 nurses in the in-patient wards. this may occur because of the accuracy and completeness of the data relating to the workload identified in the WISN method. Conclusion: WISN method can be used in calculating the need of the number of nurses in order to improve the quality of service, community satisfaction and nurses, but there are things that must be considered in the implementation of the calculation is really appropriate in identifying the completeness of workload data. It can be concluded that WISN method is not always an option to determine the number of nurses needs. The suggestion is the method used by the hospital should be adjusted to the situation and condition and characteristics of the hospital.
\end{abstract}

Keywords: WISN, Number of Nurses, Inpatient Unit, Hospital 


\section{PENDAHULUAN}

Sumber daya manusia di rumah sakit disesuaikan berdasarkan tipe rumah sakit dan pelayanan yang diberikan kepada masyarakat. Salah satu indikator keberhasilan rumah sakit yang efektif serta efisien dengan tersedianya sumber daya manusia yang memadai dengan berkualitas tinggi, profesional sesuai dengan fungsi dan tugas setiap personel.

Pimpinan rumah sakit harus memperhatikan ketersediaan sumber daya manusia di rumah sakit. Upaya-upaya yang penting dan harus dilakukan pimpinan rumah sakit adalah perencanaan kebutuhan sumber daya manusia secara tepat sesuai dengan fungsi pelayanan setiap unit, bagian, dan instalasi rumah sakit, Ilyas. Perencanaan tenaga keperawatan hingga kini masih menjadi permasalahan di berbagai rumah sakit. Masalah tersebut antara lain: kurangnya jumlah, jenis tenaga, kompetensi (pengetahuan, keterampilan, sikap dan nilai) dan kemampuan pendanaan rumah sakit yang lemah sehingga tidak dapat memenuhi dan mempertahankan sumber daya yang ada, Ilyas.

Perencanaan tenaga keperawatan merupakan fungsi manajemen rumah sakit sebagai dasar dari pelaksanaan operasional sebagai usaha mencapai tujuan organisasi, Arwani. Pemenuhan kebutuhan dasar manusia adalah salah satu upaya pelayanan keperawatan, Kuntoro. A. Formula penghitungan kebutuhan tenaga keperawatan yang ada antara lain metode Depkes RI, Depkes RI, Gillies, Formulasi Nina, Douglas, PPNI dan Full Time Equivalent (FTE), Nursalam. Metode perhitungan kebutuhan tenaga berdasarkan beban kerja nyata di setiap unit kerja fasilitas kesehatan disebut Workload Indicator Staffing Need (WISN), WHO.

Kemudahan pengoperasian, penggunaan, mudah penerapan, komprehensif dan realistis semua itu adalah kelebihan metode WISN. Metode WISN dapat mengetahui unit kerja dan kategori sumber daya manusianya, waktu kerja tersedia tiap kategori sumber daya manusia, standar beban kerja, standar kelonggaran, kuantitas kegiatan pokok dan pada akhirnya akan dapat mengetahui kebutuhan sumber daya manusia pada unit kerja tersebut. Metode WISN memiliki kelemahan yaitu sangat tergantung dari keakuratan dan kelengkapan data yang berkaitan dengan beban kerja, Mugisha dan Namaganda.

Kepmenkes Nomor 81/MENKES/I/ 2004, menganjurkan penggunaan metode WISN sebagai salah satu metode yang dianjurkan. Metode WISN merupakan salah satu indikator yang menunjukkan besarnya kebutuhan tenaga kerja disuatu unit kerja berdasarkan beban kerja, sehingga alokasi atupun relokasi akan lebih mudah dan rasional. 
Kelebihan metode ini mudah dioperasikan, mudah digunakan, secara teknis mudah diterapkan, komprehensif dan realistis. Hal inilah yang mendorong bagian sumber daya manusia RS. Gotong Royong ingin menerapkan metode penghitungan kebutuhan tenaga keperawatan yang lebih sesuai dengan karakteristik RS. Gotong Royong (RSGR) Surabaya. Hingga sekarang RS. Gotong Royong masih menggunakan metode penghitungan berdasarkan PPNI yang telah disesuaikan dengan kondisi rumah sakit dalam pemenuhan kebutuhan tenaga perawat diruang rawat inap.

RS. Gotong Royong yang beralamat di Jl. Medokan Semampir Indah No. 97 Surabaya - 60119, Telp: (+6231) 5991592; 599-1593; 593-9693. Merupakan rumah sakit umum kelas D mempunyai luas tanah $12.342 \mathrm{~m}^{2}$, luas bangunan $9.000 \mathrm{~m}^{2}$ yang terdiri dari 4 lantai, dengan kapasitas tempat tidur sebanyak 63 tempat tidur terdiri dari: ruang rawat inap dewasa, rawat inap kebidanan, ICU dan ruang rawat inap anak-anak. Sedangkan ijin opera-sional rumah sakit No.503.445/ 21/IO.RS/436. 7.2/III/2018 de-ngan masa ber-laku: 27 Maret 2018 - 27 Maret 2023. Hingga saat ini rasio kecukupan perawat masih mampu menangani pasien di unit rawat inap karena jumlah pasien rawat inap yang masih tidak terlalu banyak dan tingkat ketergantungan pasien kepada perawat masih rendah. Jika jumlah pasien yang rawat inap masuk rawat inap secara bersamaan dan mempunyai tingkat ketergantungan yang tinggi kepada perawat maka instalasi rawat inap akan merasakan beban kerja yang tinggi.

Berdasarkan fenomena tersebut RS. Gotong Royong ingin menentukan jenis penghitungan tenaga keperawatan pada instalasi rawat inap yang lebih sesuai pada saat jumlah pasien yang sedang dirawat dalam jumlah banyak, pada akhirnya mutu pelayanan yang diberikan kepada pasien akan meningkat. Pada permasalahan tersebut dilakukan analisis kebutuhan riil tenaga perawat di unit irna dewasa dan ruang irna anak dengan melakukan pengkajian kebutuhan tenaga berdasar beban kerja nyata.

5 langkah cara perhitungan berdasarkan WISN, antara lain: yaitu 1) waktu kerja tersedia ditetapan berdasarkan banyaknya hari kerja, cuti, pendidikan dan pelatihan, hari libur nasional, ketidakhadiran kerja dan waktu kerja tenaga kesehatan selama satu tahun, 2) menetapkan unit kerja dan kategori sumber daya manusia yang dihitung, 3) disusunnya standar beban kerja, 4) penyusunan standar kelonggaran, 5) Penghitungan kebutuhan tenaga perunit kerja, Ernawati. Penelitian ini bertujuan untuk mendapatkan jumlah kebutuhan tenaga keperawatan yang lebih sesuai bagi 
unit rawat inap dewasa dan unit rawat inap anak di rumah sakit Gotong Royong dengan menggunakan metode WISN.

\section{BAHAN DAN METODE}

Penelitian ini merupakan penelitian analitik observasional dengan menggunakan metode pendekatan Time and Motion Study. Sampel dalam penelitian ini ditentukan dengan metode purposive sampling, yaitu semua perawat pelaksana di ruang rawat inap dewasa dan ruang rawat inap anak yang bertujuan untuk melihat aktivitas atau kegiatan secara menyeluruh dari perawat pelaksana dalam rangka menganalisis beban kerja perawat pelaksana untuk merencanakan jumlah kebutuhan tenaga perawat di ruang rawat inap dewasa dan ruang rawat inap anak RS. Gotong Royong.

Populasi adalah semua perawat di ruang rawat inap anak dan ruang rawat inap dewasa Rumah Sakit Gotong Royong. Langkah yang dilakukan pada penelitian ini adalah pengamatan pendahuluan, penentuan jumlah pengamatan, penentuan waktu pengamatan, penentuan aktivitas work dan idle, pengamatan work sampling, penentuan allowance dan penentuan kebutuhan sumber daya manusia dengan metode Workload Indicator Staff Need (WISN).

Rentang waktu penelitian dari tanggal 02 April sampai 21 Mei 2018. Penelitian ini dilaksanakan di ruang rawat inap dewasa dan ruang rawat inap anak. Adapun pemilihan kedua ruangan tersebut didasarkan pada pertimbangan bahwa kedua ruangan tersebut masih sering terdapat masalah kekurangan tenaga perawat. Tenaga perawat yang diamati sebanyak 17 orang perawat pelaksana yaitu 9 perawat di ruang rawat inap dewasa dan 8 perawat di ruang rawat inap anak. Dalam satu hari peneliti mengamati satu orang perawat, sesuai shift jaga (shift pagi, shift sore dan shift malam). Setiap perawat diobservasi sebanyak satu kali yaitu pada shift pagi, sore dan malam.

Pengamatan diruang rawat inap lantai 3 dilaksanakan dari tanggal 02 April sampai 23 April 2018 dan di ruang rawat inap anak dilaksanakan dari tanggal 23 April sampai 21 Mei 2018. Selanjutnya dimasukkan ke dalam rumus perhitungan jumlah tenaga dari Workload Indicators of Staff Need (WISN).

\section{Metode WISN}

$\mathrm{WKT}=(\mathrm{A}-(\mathrm{B}+\mathrm{C}+\mathrm{D}+\mathrm{E})) \times \mathrm{F}$

Keterangan:

WKT $=$ Waktu Kerja Tersedia

$\mathrm{A}=$ Hari kerja yang mungkin dalam setahun

$\mathrm{B}=$ Cuti tahunan

$\mathrm{C}=$ Pendidikan\&Pelatihan

$\mathrm{D}=$ Hari Libur Nasional

$\mathrm{E}=$ Ketidakhadiran Kerja

$\mathrm{F}=$ Waktu kerja dalam satu hari 


\section{HASIL}

Dari penelitian ini didapatkan jenis kelamin responden, dari 17 tenaga perawat di ruang rawat inap dewasa dan ruang rawat inap anak semuanya: $100 \%$ adalah berjenis kelamin perempuan. Tingkat pendidikan perawat di ruang rawat inap dewasa $100 \%$ adalah DIII Keperawatan. Sedangkan tenaga perawat di ruang rawat inap anak $75 \%$ adalah DIII Keperawatan dan 25\% adalah S1 Keperawatan. Status kepegawaian perawat di ruang rawat inap dewasa $88,88 \%$ adalah karyawan tetap dan $11,12 \%$ karyawan tidak tetap.

Di ruang rawat inap anak 100\% berstatus karyawan tetap. Masa kerja tenaga perawat di ruang rawat inap dewasa 33,33\% antara 1- 5 tahun, 66,67\% lebih dari 5 tahun. Masa kerja perawat di ruang rawat inap anak $12,5 \%$ kurang dari 1 tahun, $75 \%$ antara 1-5 tahun dan $12,5 \%$ lebih dari 5 tahun. Beban kerja obyektif perawat dinyatakan dalam bentuk proporsi waktu kerja yang dikelompokkan menjadi tindakan keperawatan langsung (tugas pokok) dan tindakan keperawatan tidak langsung (tugas penunjang) merupakan kegiatan produktif tenaga keperawatan. Kegiatan non keperawatan merupakan kegiatan non produktif tenaga keperawatan.

Dari Hasil analisa beban kerja perawat tersebut dapat dijadikan dasar untuk mengetahui proporsi waktu yang digunakan untuk kegiatan keperawatan secara langsung, tidak langsung maupun pribadi, pola beban kerja perawat pelaksana dengan waktu jadwal jam kerja, dan mengetahui jumlah kebutuhan tenaga perawat di rumah sakit.

Berdasarkan penghitungan kebutuhaan tenaga perawat berdasarkan Workload Indikator Staff Need (WISN) menunjukkan berdasarkan waktu kerja tersedia adalah $1.954 \mathrm{jam} / \mathrm{tahun}$ (117240 menit/tahun), atau 279,1 hari kerja, dari segi menetapkan unit kerja unit kerja yang menjadi fokus dalam penelitian ini adalah tenaga perawat pelaksana di ruang rawat inap dewasa dan ruang rawat inap anak RS. Gotong Royong, standar beban kerja tenaga keperawatan di ruang rawat inap dewasa adalah sebesar 2008224/tahun dan di ruang rawat inap anak adalah sebesar 1693714/tahun, sedangkan dari segi menyusun standar kelonggaran di ruang rawat inap dewasa rumah sakit Gotong Royong adalah 0,24 dan di ruang rawat inap anak adalah 0,24 dari segi Berdasarkan penghitungan metode WISN kebutuhan tenaga perawat di unit kerja dapat diketahui, jumlah kebutuhan tenaga perawat di ruang rawat inap dewasa adalah sebanyak 10 perawat dan 8 perawat di ruang rawat inap anak RS. Gotong Royong. 
Tabel 1 Tingkat pendidikan perawat di irna dewasa dan irna Anak RS. Gotong Royong

\begin{tabular}{|c|l|r|r|c|c|c|}
\hline \multirow{2}{*}{ No } & \multirow{2}{*}{ Ruang } & \multicolumn{5}{|c|}{ JenisKelamin } \\
\cline { 3 - 7 } & D3 & \% & S-1 & \% & Total \\
\hline 1 & $\begin{array}{l}\text { Ranap } \\
\text { Dewasa }\end{array}$ & 9 & 100 & 0 & 0 & 100 \\
\hline 2 & Ranap Anak & 6 & 75 & 2 & 25 & 100 \\
\hline
\end{tabular}

Tabel 2 Masa kerja perawat di ruang rawat inap dewasa dan ruang ranap anak

\begin{tabular}{|c|c|r|r|r|r|}
\hline \multirow{2}{*}{ No } & \multirow{2}{*}{$\begin{array}{l}\text { Kasa } \\
\text { Kerja }\end{array}$} & \multicolumn{2}{c|}{ Ranap Dewasa } & \multicolumn{2}{c|}{ Ranap Anak } \\
\cline { 3 - 6 } & & $\mathrm{n}$ & $\%$ & $\mathrm{n}$ & $\%$ \\
\hline 1 & $<1$ tahun & 0 & 0 & 1 & 12,5 \\
\hline 2 & $1-5$ tahun & 3 & 33,33 & 6 & 75 \\
\hline 3 & $>5$ tahun & 6 & 66,67 & 1 & 12.5 \\
\hline \multicolumn{2}{|r|}{ Total } & 9 & 100 & 8 & 100 \\
\hline
\end{tabular}

Tabel 3 Standar Kelonggaran Waktu, Standar Beban Kerja, dan Jumlah Kebutuhan Tenaga Keperawatan di Ruang Rawat Inap dewasa RS. Gotong Royong tanggal 02 April-23 April 2018

\begin{tabular}{|c|c|c|c|c|}
\hline \multirow[t]{2}{*}{ No } & \multirow{2}{*}{$\begin{array}{l}\text { Kegiatan } \\
\text { Produktif }\end{array}$} & \multicolumn{3}{|c|}{ Rawat Inap Dewasa } \\
\hline & & $\begin{array}{c}\text { WKT } \\
\text { (JAM/THN) }\end{array}$ & SBK & SK \\
\hline 1 & $\begin{array}{l}\text { Tindakan } \\
\text { Keperawatan } \\
\text { Langsung }\end{array}$ & \multirow[t]{3}{*}{1954} & $\begin{array}{l}6.2344 \\
80553\end{array}$ & \multirow[t]{3}{*}{0.24} \\
\hline 2 & $\begin{array}{l}\text { Tindakan } \\
\text { keperawanan } \\
\text { Tidak } \\
\text { Langsung }\end{array}$ & & $\begin{array}{l}3.1946 \\
86114\end{array}$ & \\
\hline \multicolumn{2}{|c|}{ Total } & & $\begin{array}{l}9.4291 \\
66667\end{array}$ & \\
\hline \multicolumn{2}{|c|}{$\begin{array}{l}\text { Jumlah Kebutuhan } \\
\text { Tenaga }\end{array}$} & & 10 & \\
\hline
\end{tabular}

Tabel 4 Standar Beban Kerja, Standar Kelonggaran Waktu dan Jumlah Kebutuhan Tenaga Keperawatan Ruang Rawat Inap Anak RS. Gotong Royong tanggal 23 April - 21 Mei 2018

\begin{tabular}{|c|l|c|c|c|}
\hline \multirow{2}{*}{ No } & \multirow{2}{*}{$\begin{array}{c}\text { Kegiatan } \\
\text { Produktif }\end{array}$} & \multicolumn{3}{|c|}{ Rawat Inap Dewasa } \\
\cline { 4 - 5 } & $\begin{array}{c}\text { WKT } \\
\text { (JAM/THN }\end{array}$ & SBK & SK \\
\hline \multirow{2}{*}{1} & Tindakan & & & \\
& Keperawatan & & 5.99249 & \\
& Langsung & 1954 & 8294 & 0.24
\end{tabular}

\begin{tabular}{|c|c|c|}
\hline 2 & $\begin{array}{l}\text { Tindakan } \\
\text { keperawanan } \\
\text { Tidak } \\
\text { Langsung }\end{array}$ & $\begin{array}{c}1.60282 \\
3269\end{array}$ \\
\hline \multicolumn{2}{|c|}{$\frac{1}{\text { Total }}$} & $\begin{array}{c}7.59532 \\
1563\end{array}$ \\
\hline \multicolumn{2}{|c|}{$\begin{array}{l}\text { Jumlah Kebutuhan } \\
\text { Tenaga }\end{array}$} & 8 \\
\hline
\end{tabular}

\section{PEMBAHASAN}

Bed occupancy rate (BOR) adalah presentase pemanfaatan jumlah tempat tidur di rumah sakit. Pencapaian angka $B O R$ yang cukup tinggi mengindikasikan tingkat kebutuhan terhadap jumlah tenaga perawat juga semakin tinggi. Pencapaian angka $B O R$ berpengaruh secara signifikan terhadap kebutuhan tenaga perawat, hal ini mengindikasikan bahwa kebutuhan jumlah tenaga perawat yang sesuai akan meningkatkan pencapaian angka BOR yang cukup, Susanto.

Jumlah tempat tidur tidak banyak mempengaruhi jumlah tenaga perawat, sebab walaupun pihak rumah sakit menyediakan jumlah tempat tidur berjumlah banyak tetapi jika tidak dimanfaatkan dengan baik oleh pasien atau jumlah kunjungan pasien yang datang berobat pada instalasi rawat inap kurang. Jumlah jam perawatan pasien selama 24 jam adalah jumlah keseluruhan jam perawatan pasien yang dirawat selama 24 jam berdasarkan kategori pasien yang ada diinstalasi rawat inap, Ilyas. 
Semakin meningkat jumlah jam perawatan pasien selama 24 jam maka kebutuhan akan jumlah tenaga perawat juga akan lebih meningkat pula. Hal ini berarti semakin banyak jumlah jam perawatan pasien selama 24 jam semakin banyak pula kebutuhan jumlah tenaga perawat yang dibutuhkan oleh pasien rawat inap pada rumah sakit. Beban kerja perawat merupakan keseluruhan kegiatan aktivitas yang dilakukan oleh seorang perawat saat bertugas di unit pelayanan keperawatan. Perawat yang mengalami kelelahan dalam bekerja dapat menyebabkan terjadinya penyimpangan kerja yang akan menyebabkan kemunduran penampilan kerja, Tappen.

Pengukuran beban kerja obyektif dilakukan untuk mengetahui penggunaan waktu tenaga keperawatan dalam melaksanakan kegiatan produktif dan non produktif pada setiap shift kerja yaitu shift pagi, sore dan malam, Marquish Grace Detroit menyatakan bahwa rerata waktu yang dibutuhkan untuk perawatan tidak langsung adalah 36 menit/klien/hari, Gillies. Interpretasi hasil penghitungan kebutuhan tenaga perawat berdasarkan indeks WISN didapatkan ruang rawat inap dewasa mengindikasikan terdapat kekurangan 1 tenaga perawat, sedangkan di ruang rawat inap anak telah sesuai dengan keadaan riil yang ada sekarang.
Kekurangan tenaga perawat di ruang rawat inap dewasa dapat dikarenakan adanya beberapa kegiatan keperawatan yang masih belum teridentifikasi dengan baik sehingga akan menambah beban waktu kerja perawat di ruang rawat inap dewasa. Pada penelitian ini menunjukkan standar beban kerja untuk menyelesaikan kegiatan produktif di ruang rawat inap dewasa adalah 9.429166667 yang meliputi tindakan keperawatan langsung sebesar 6.234480553 dan tindakan keperawatan tidak langsung sebesar 3.194686114.

Total standar beban kerja perawat di ruang rawat inap anak adalah 7.595321563 yang meliputi tindakan keperawatan langsung sebesar 5.992498294 dan tindakan keperawatan tidak langsung sebesar 1.602823269. Perawat yang telah mencapai waktu kerja produktif tinggi, menunjukkan beban kerja tinggi pula sehingga perlu diperhatikan dan pertimbangan unit tersebut membutuhkan tenaga perawat tambahan. Penentuan standar beban kerja memerlukan usaha yang lebih, karena akan mempengaruhi jumlah kebutuhan tenaga perawat yang dibutuhkan.

Jadi identifikasi semua jenis kegiatan keperawatan di ruang rawat inap harus dilakukan secara detail termasuk lama waktu yang diperlukan oleh seorang perawat dalam melakukan kegiatan kepera-watan tersebut. Penentuan standar 
kelonggaran waktu juga terjadi perdebatan yang panjang, hal ini terjadi karena adanya perbedaan pendapat dari masingmasing perawat baik di ruang rawat inap dewasa maupun di ruang rawat inap anak, sehingga perlu pembahasan secara bersama sama untuk mendapatkan kesepakatan antara perawat dan bagian sumber daya manusia untuk menentukan standar kelonggaran.

Karena standar kelonggaran yang lama akan mempengaruhi penambahan jumlah tenaga perawat yang ada. Tidak jarang perawat di ruang rawat inap dewasa dan ruang rawat inap anak berusaha mengindikasikan beban kerja yang lama dan pada akhirnya hal ini juga akan memperpanjang waktu pelaksanaan pekerjaan. Hal ini akan berdampak seorang perawat akan mendapat penghitungan kebutuhan tenaga yang besar, hal ini dimaksudkan supaya tenaga di unitnya tidak dikurangi.

Penelitian ini juga menunjukkan bahwa mempertimbangkan untuk mengidentifikasi kegiatan-kegiatan keperawatan yang belum ada sebelumnya sehingga diharapkan akan dapat menunjukan kekurangan tenaga perawat yang akan menyebabkan performa seorang perawat dalam memberikan pelayanan di rumah sakit menghasilkan kinerja yang buruk. Hasil perhitungan tenaga berdasarkan WISN sesuai bila dibandingkan dengan perhitungan ratio perawat dengan jumlah tempat tidur menurut Depkes untuk kategori rumah sakit tipe C, Depkes.

\section{KESIMPULAN}

Kebutuhan tenaga perawat berdasarkan Workload Indicator Staff Need (WISN) di ruang rawat inap dewasa masih terdapat kekurngan 1 orang tenaga perawat (tenaga perawat yang ada 9 perawat) sedangkan di ruang rawat inap anak menunjukan hasil jumlah tenaga perawat yang sama dengan yang ada saat ini yaitu sebanyak 8 orang perawat.

\section{SARAN}

Hasil penelitian ini dapat dijadikan bahan pertimbangan manajemen utamanya bagian sumber daya manusia rumah sakit untuk mengambil kebijakan untuk melakukan penambahan tenaga perawat di ruang rawat inap dewasa. Selanjutnya perlu dilakukan penelitian penghitungan kebutuhan tenaga perawat berdasarkan WISN di unit kerja yang lain.

\section{DAFTAR PUSTAKA}

Arwani dan Supriyatno, H. Manajemen Bangsal Keperawatan. Jakarta: Penerbit Buku Kedokteran EGC; 2006.

Ernawati, Ni luh Ade Kusuma. Kebutuhan Rill Tenaga Perawat dengan Metode Workload Indicator Staff Need (WISN). Jakarta: Universitas Airlangga. 2011.

Ilyas, Y. Perencanaan Sumber Daya Manusia Rumah Sakit. Teori Metoda dan Formula. Jakarta: Pusat Kajian Ekonomi Kesehatan FKM UI; 2004. 
Kuntoro Agus. Buku Ajar Manajemen Keperawatan. Yogyakarta: Nuha Medika, 2010. Departemen Kesehatan Republik Indonesia.

Mugisha, J.F, dan G. Namaganda. Using the Workload Indicators of Staffing Need (WISN) Methodology to Assess Work Pressure Among the Nursing Staff of Lacor Hospital. Health Policy and Development Journal, Vol 6; Edisi 1: 1-15. 2008.

Nursalam. 2007. Manajemen Keperawatan Aplikasi dalam Praktik Keperawatan Profesional. Jakarta: Salemba Medika.

User's Manual. [internet]. 2010 [cited 2010 Apr2018]. Available from: http:// whqlibdoc.who.int/publications/2010/ 9789241500197_users_eng.pdf\&ved $=0$ CCAQFjAB\&ug=AFQjCNGttCKD_g8 x8w4x5LeoERlvYh86z A\&sig2=Aw1 NfurJfFNJLsR5suc9Qw

Standar Tenaga Keperawatan di Rumah Sakit. Jakarta: Direktorat Keperawatan dan Keteknisan Medik, Direktorat Jenderal Pelayanan Medik. 2005.

Susanto. A. B. Reputation-Driven Corpo rate Social Responsibility. Jakarta Esensi; 2009

Tappen. R. M., Weis. S. A., and Whitehead. D.K., Essential of Nursing leadership., Philadelphia: F.A. Davis Company. 1998 